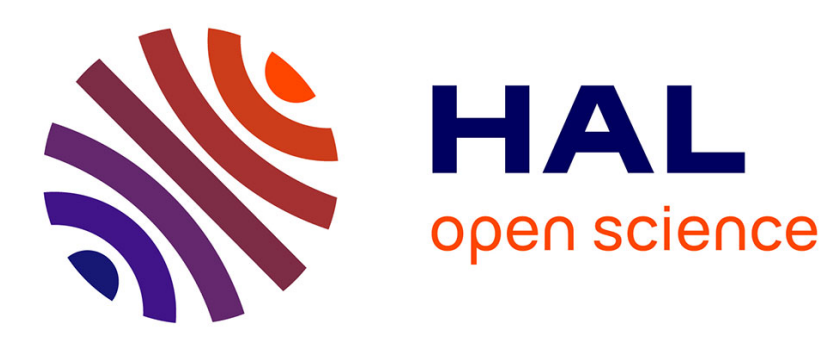

\title{
Submarine Landslides caused by Seamounts entering Accretionary Wedge Systems
}

\author{
Jonas B. Ruh
}

\section{To cite this version:}

Jonas B. Ruh. Submarine Landslides caused by Seamounts entering Accretionary Wedge Systems. Terra Nova, 2016, 28 (3), pp.163-170 10.1111/ter.12204 . hal-01289133

\section{HAL Id: hal-01289133 https://hal.sorbonne-universite.fr/hal-01289133}

Submitted on 16 Mar 2016

HAL is a multi-disciplinary open access archive for the deposit and dissemination of scientific research documents, whether they are published or not. The documents may come from teaching and research institutions in France or abroad, or from public or private research centers.
L'archive ouverte pluridisciplinaire HAL, est destinée au dépôt et à la diffusion de documents scientifiques de niveau recherche, publiés ou non, émanant des établissements d'enseignement et de recherche français ou étrangers, des laboratoires publics ou privés. 


\section{Submarine Landslides caused by Seamounts entering Accretionary}

\section{Wedge Systems}

4 Jonas B. Ruh*

5 *Institut de la Science de Terre, Université Pierre et Marie Curie, Paris, France

6

Seamounts entering active subduction zone trenches initially collide with the frontal sedimentary accretionary wedges resulting in severe deformation of the overriding plate. A typical feature of this deformation is the occurrence of submarine landslides due to gravitational instabilities. Such landslides have been reported from the Middle America and the Hikurangi trench and potentially generate tsunami waves. Yet, the dynamics of accretionary wedges during seamount indentation and landsliding as a mechanical response in particular have not been investigated quantitatively. Here, I apply 3D high-resolution numerical experiments to show that the topographical evolution of an accretionary wedge is mainly depending on the volume of the entering seamount and not on its height. Submarine landslides only occur if seamounts are not completely buried by the sedimentary sequence, where the volume of avalanches can be roughly correlated with the seamount volume overtopping the incoming sediments.

\section{INTRODUCTION} Seamounts, or submarine volcanoes, are distributed among all oceanic plates around the globe (Hillier and Watts, 2007; Smith and Jordan, 1988). Although most of those are rather small, it has been suggested that around 12'000 large seamounts $(>1.5 \mathrm{~km})$ cover the ocean floors (Watts et al., 2010; 
24 Wessel et al., 2010). Seamounts differ in height and may exhibit either conical shapes (peaked),

25 multiple branches (star shaped), and some can be flat-topped (Schmidt and Schmincke, 2002). Along

26 active convergent margins, seamounts enter subduction zones and eventually collide with overriding

27 plates. Observations of seamount subduction at active margins are documented from the Tonga-

28 Kermandec trench (Timm et al., 2013), Nankai trench (Bangs et al., 2006), Japan and Kuril trench

29 (Lallemand et al., 1989; Nishizawa et al., 2009), Cascadia (Wells et al., 1998), New Hebrides (Collot

30 and Fisher, 1994), Hikurangi trench (Pedley et al., 2010), Middle America trench (von Huene, 2008),

31 Central Chile margin (Laursen et al., 2009), Central Mariana and Izu-Bonin trenches (Oakley et al.,

32 2008), Mediterranean ridge (von Huene et al., 1997), and Aleutian trench (Das and Watts, 2009).

33 Relatively large seamounts are truncated when reaching the fore arc at shallow levels and may

34 potentially be decapitated at larger depths, related to seismogenic deformation (Cloos, 1992). But

35 whether seamounts along subduction interfaces trigger large earthquakes, form natural barriers for

36 earthquake propagation, or even decrease seismic coupling between two plates is still a matter of

37 debate (Mochizuki et al., 1997; Scholtz and Small, 1997; Das and Watts, 2009; Watts et al., 2010;

38 Wang and Bilek, 2011).

Before a seamount reaches the fore arc, it traverses the frontal sedimentary accretionary wedge

40 causing severe impact on the morphologic and tectonic evolution of the overriding plate. Topographic

41 uplift above seamounts formes bulges (Park et al., 1999). Slope failure of such supercritical bulges

42 (Lallemand and Le Pichon, 1987) occur that can trigger submarine avalanches (Lewis et al., 1998;

43 Pedley et al., 2010). Such submarine avalanches (or landslides) can in turn cause major human and

44 economic impact in the form of tsunamis (Fisher et al., 2005; Tappin et al., 2014), or demolition of

45 offshore pipelines (Liu et al., 2015).

Collision of seamounts into accretionary systems have been dynamically reconstructed with analogue models that could reproduce main features of observed upper plate deformation (Lallemand et 
49 far investigating the effect of seamount subduction on deformation localization within the upper plate

50 in general and the occurrence of gravitational submarine landslides in particular.

Due to the prevalent distribution of seamounts along subduction trenches and their geohazard

52 potential, it is essential to understand the mechanics and dynamics of developing accretionary wedges

53 during collision with a seamount. Therefore, I here test the influence of seamount size and shape on the

54 tectonic and mechnical evolution of accretionary wedges with main focus on gravitational collapse and

55 submarine landslides by applying a high-resolution three-dimensional numerical code. Results are

56 discussed in the scope of the analytical critical wedge theory.

\section{APPLIED GEOMETRICAL SETUP}

Numerical model and setup are similar to those documented in earlier studies (Ruh et al., 2013; 2014), and are based on a three-dimensional, high-resolution, fully-staggered grid, finite difference, marker-in-cell code with a standard visco-brittle/plastic rheology and an efficient OpenMP-parallelized multigrid solver (I3ELVIS; Gerya, 2010; Gerya and Yuen, 2007; see supplementary material). Eulerian grid dimensions of presented simulations are $97.6 \cdot 97.6 \cdot 14.8 \mathrm{~km}$ in $x$-, $y$-, $z$-directions with a nodal resolution of $245 \cdot 245 \cdot 149$, respectively; resulting cell size is $400 / 400 / 100 \mathrm{~m}$, each containing 8 Lagrangian markers. Accordingly, the code calculates for $\sim 9$ million nodes and $\sim 70$ million markers. The geometrical setup resembles typical "sandbox"-type models. Initial marker distribution defines a $300 \mathrm{~m}$

67 thick lowermost rigid plate, topped by a $500 \mathrm{~m}$ thick décollement and $3 \mathrm{~km}$ of sedimentary sequence.

68 Above, $11 \mathrm{~km}$ of "sticky-air" mimic a free surface allowing wedge to thicken. At the bottom, the rigid 69 plate moves with a velocity $v_{x}=-1 \mathrm{~cm} / \mathrm{yr}$ and is pulled out below the lateral boundary at $x=0$, which

70 acts as a rigid backstop (no slip). On the opposite boundary, new stratigraphy is entering the Eulerian

71 grid with $v_{x}$. Lateral side and top boundaries are free slip. Seamounts root into the rigid bottom plate

72 and are introduced opposite of the backstop into undeformed stratigraphy after 4 Myr runtime.

73 Plastic/brittle failure is based on the Drucker-Prager formulation depending on pressure $P$, friction an- 
74 gle $\varphi$, cohesion $C$, and fluid pressure ratio $\lambda$ (Ruh et al., 2014). Décollement: $\varphi_{b}=10^{\circ}$ and $C_{b}=0.2$

$75 \mathrm{MPa}$. Sedimentary sequence: $\varphi=30^{\circ}$ and $C=10 \mathrm{MPa}$. Seamounts: $\varphi=30^{\circ}$ and $C=20 \mathrm{MPa}$. A hydro-

76 static fluid pressure ratio $\lambda=0.4$ is applied for décollement and sediments. Sediments and seamounts

77 are weakened by linearly lowering $\varphi$ to $20^{\circ}$ and $C$ to $0.2 \mathrm{MPa}$ according to plastic strain $\varepsilon_{p l}$ between 0.5

$78<\varepsilon_{p l}<1.5$ (Ruh et al., 2013). A total of nine simulations are presented here: One model without

79 seamount implementation acts as reference, eight simulations were carried out to investigate effects of

80 size and shape of seamounts on upper plate deformation. Modeled seamounts rise 1.5, 3, 4.5, or $6 \mathrm{~km}$

81 high (above the décollement level) with either conical or flat-topped shapes. Seamounts are round with

82 a lateral slope of $30^{\circ}$, which is on the upper level of naturally observed seamount slopes (Figure 1 in

83 Dominguez et al., 1998). Flat-topped seamounts exhibit a horizontal cap with a radius of $5 \mathrm{~km}$.

85 TOPOGRAPHIC EVOLUTION DURING SEAMOUNT SUBDUCTION

Deformation of numerical accretionary wedges localizes along the backstop and the

deformation front migrates outward in-sequence with ongoing shortening (Gif 1 in supplementary material). Frontal accretion and out-of-sequence thrusting assure wedge growth in width ( $x$-direction) and thickness, respectively, leading to a wedge body thickened at the rear $(x=0)$ thinning towards the toe (Fig. 1a). The topographic evolution of compressive wedges varies strongly depending on size and

91 shape of entering seamounts. A conical seamount with a height of $1.5 \mathrm{~km}$ (above the décollement level)

92 leaves a trace only in the thrust sheet that was the frontal one at the time of seamount entrance into the

93 wedge (Fig. 1b). Simulations with higher conical seamounts exhibit topographic peaks spatially related

94 to the seamount location and several thrust sheets are deformed due to its entrance (Fig. 1c-e). The

95 topographic response of accretionary wedges to flat-topped seamount subduction is more prominent. A

$961.5 \mathrm{~km}$ high semount leaves a clear trace in the accreting thrust sheets (Fig. 1f). Higher flat-topped

97 seamounts form wide entrances into the wedge front and there are no cylindrical frontal thrust sheets 
98 developing within 9 Myr (Fig. 1g-i). Topographic peaks induced by underthrusting seamounts are

99 always located at the rearward side of the seamount top (Fig. 1).

100 The elevation of these topographic peaks increases with increasing seamount height.

101 Nonetheless, peak elevations of flat-topped seamount experiments are substantially higher than those

102 with equally high conical seamounts. After 9 Myr, experiments of flat-topped seamounts with 1.5 and 3

$103 \mathrm{~km}$ height (Fig. 1f,g) exhibit similar surface topographic reliefs as models with 4.5 and $6 \mathrm{~km}$ high

104 conical seamounts (Fig. 1d,e), respectively: Only from the topographic map is not possible to

105 determine whether the underthrusting seamount is flat-topped with $3 \mathrm{~km}$ height or conical with $6 \mathrm{~km}$

106 height (Fig. 1e,g).

107 Yet, peak elevations strongly dependent on the volume of seamounts entering an accretionary

108 wedge (Fig. 2). This relation between the volume of a seamount and the peak elevation of overthrusting

109 imbricate sheets is independent of the temporal evolution of seamount collision into an accretionary

110 wedge. The similar differences of topographic peaks between 7 and $8 \mathrm{Myr}$ and between 8 and $9 \mathrm{Myr}$,

111 respectively, indicate a linear vertical thickening of accretonary wedges over time, independent of

112 shape and height of subducting seamounts (Fig. 2).

\section{SUBMARINE LANDSLIDES TRIGGERED BY SEAMOUNTS}

115 It is widely accepted that seamounts entering subduction zones are a potential trigger of

116 submarine landslides due to gravitational collapses (e.g., Lallemand and Le Pichon, 1987; Hühnerbach

117 et al., 2005). Nevertheless, the dynamics of such avalanches and their volumetric and temporal relation

118 to subducting seamounts have yet to be investigated.

119 The collision of a seamount has a major impact on the mechanical evolution of accretionary

120 wedges, regardless whether submarine landslides appear or not (Gifs 2-9 in supplementary material).

121 Seamounts act as barriers for the migration of the deformation front as they interrupt the flat

122 décollement. The gravitational potential of sedimentary strata overthrusting seamounts activates the 
123 décollement level on the toeward side of the seamount and a normal fault along the seamount develops

124 (Gifs 2-9 in supplementary material). Experiments exhibiting seamounts that exceed the initial

125 sedimentary sequence build up large enough gravitational forces within the overthrust stratigraphy to

126 trigger gravitational collapses (Gifs 4,5,8,9 in supplementary material). In case of a $6 \mathrm{~km}$ high flat-

127 topped seamount, stacked material atop of the seamount fails along a listric-like normal fault and

128 emplaces an up to $1.5 \mathrm{~km}$ thick sequence in front of the seamount (Fig. 3a). Strain rates indicate that

129 the emplacement of the landslide activates the décollement toewards from the seamount and puts the

130 undeformed sedimentary sequence at the verge of failure (Fig. 3b). A steep main scarp, a listric fault, a

131 thin rupture surface, and a partly undeformed landslide mass are very well constrained features of

132 observed submarine landslides (Hampton et al., 1996). Velocity field in $x$-direction indicates that the

133 material above the active listric fault moves away from the rear (Fig. 3c; such slow velocities result

134 from lower viscosity cutoff: $\left.10^{18} \mathrm{~Pa} \cdot \mathrm{s}\right)$. Low velocities of displaced material patches along the wedge

135 toe indicate an earlier landslide.

136 A topographic peak above the seamount and surpress frontal accretion due to the seamount

137 interrupting the décollement level (Fig. 3) lead to a steepening of the surface taper along the profile

138 where the seamount subduct $(y=48.8 \mathrm{~km})$, as observed in seismic profiles through the Nankai

139 accretionary wedge (Park et al., 1999). The temporal evolution of surface slope of a compressional

140 wedge without seamount implementation (Gif 1 in supplementary material) indicates a taper leveling

141 along the analytical minimum critical value within the stable regime (Fig. 4a). Dynamic surface tapers

142 of seamount experiments are calculated from surface points located between the seamount top and the

143 wedge toe, where a continuous décollement layer exists in between (Davis et al., 1983).

144 Submarine landslides decrease surface slopes (Fig. 4a,b). Tapers move from the supercritical

145 into the stable field (below the maximum critical value) where they remain at $6-8^{\circ}$. This demonstrates

146 that modeled wedges are behaving critical and that landslides are triggered by brittle/plastic

147 gravitational collapses. Slope profiles along subduction zones where seamounts enter can therefore 
148 give insight in the strength relationship between basal and wedge internal material, expecting that

149 tapers away from seamount occurrences represent the minimum analytical value, whereas profiles

150 along seamount scars are close to maximum critical tapers (Geersen et al., 2015).

\section{SIZE OF SUBMARINE LANDSLIDES}

153 The volume of the dislocated mass during submarine landslides triggered by seamount

154 subduction differs strongly for conical and flat-topped seamounts (Fig. 4c,d). A $4.5 \mathrm{~km}$ high conical

155 seamount triggers a short-living landslide with a volume of $\sim 20 \mathrm{~km}^{3}$ (Fig. $4 \mathrm{c}$ ). A $6 \mathrm{~km}$ conical

156 seamount launches an up to $60 \mathrm{~km}^{3}$ large avalanche that is active over a longer period of time. Initial

157 activation of landslides are contemporaneous with the strong decrease of surface taper between 7 and 8

158 Myr of experiment evolution (Fig. 4a,c). Flat-topped seamounts cause much larger landslides. Peak

159 volumes reach $\sim 300 \mathrm{~km}^{3}$ for $4.5 \mathrm{~km}$ high and up to $500 \mathrm{~km}^{3}$ for $6 \mathrm{~km}$ high seamounts (Fig. 4d). The

160 landslide remains active from its initiation at 7.7 Myr to the leveling of surface taper within the stable

161 area at 9 Myr (Fig. 4b,d). On the basis of these results, a first-order estimation of landslide volume can

162 be inferred from the volume of entering seamounts overtopping the initial sedimentary sequence (Fig.

$1634 \mathrm{c}, \mathrm{d}$ ), which also agrees with the absence of landslides for seamounts shorter than the stratigraphic

164 thickness of $3 \mathrm{~km}$.

165 Numerical submarine landslides presented here can be compared to reported natural cases and

166 estimations for their tsunamigenic potential can furthermore be provided. In general, numerical

167 avalaches are volumetrically comparable to ordinary submarine landslides triggered by gravitational

168 instabilities ( $<800 \mathrm{~km}^{3}$; Hampton et al., 1996; and references therein). An example of landsliding

169 caused by seamount collision is documented along the Hikurangi margin (Lewis et al., 2004). The

170 Giant Ruartoria avalanche off New Zealand has a volume of $\sim 2000 \mathrm{~km}^{3}$ and is a result of collision of

171 the now subducted Ruatoria seamount into the Hikurangi accretionary wedge (Collot et al., 2001). The 
172 size of Ruatoria seamount is interpreted to be similar to that of Gisborne seamount offshore Hikurangi,

173 whose overtop volume can roughly be compared to the reported avalanche volume.

$174 \quad$ Figure 5 illustrates a comparison between the Ruatoria indentation and related avalanche and

175 the numerical collision of a flat-topped $6 \mathrm{~km}$ high seamount into a developing accretionary wedge

176 presented in this study (Fig. 3). In both cases, landsliding results from oversteepening and collapse of

177 the wedge front due to seamount indentation (Fig. 5). In the natural as well as the numerical case,

178 volumes of avalanches and exceeding seamounts are roughly similar.

179 A potential of tsunami generation is apparent from a fault scar volume larger than $\sim 10 \mathrm{~km}^{3}\left(\mathrm{van}^{2}\right.$

180 Huene et al., 2004), which includes all presented experiments with a seamount height greater than the 181 initial sedimentary sequence (Fig. 4c,d). Yet, also smaller volumes of landslides have been interpreted

182 to be potentially tsunamigenic (Borrero et al., 2001; Fisher et al., 2005). Mass movements similar to

183 here reported can generate up to $50 \mathrm{~m}$ high tsunamis (von Huene et al., 1989). Trench areas where

184 rough and seamount covered oceanic crust is entering a subduction zone are in a critical stress state and

185 the interplay between seismic events, submarine landslides, and tsunami waves was reported for the

1861992 Central Nicaragua earthquake (von Huene et al., 2004). Reentrants and scars indicate seamount

187 collision and taper angles with a high potential of gravitational failure during earthquakes. Experiments 188 presented here show that potential landslide volumes can be directly correlated to the (overtop) volume 189 of seamount.

\section{ACKNOWLEDGMENTS}

192 I am very thankful to Taras Gerya, who provided the numerical code. Funding was received

193 from the People Programme (Marie Curie Actions) of the European Union's Seventh Framework

194 Programme FP7/2007-2013/ under REA grant agreement n 604713 (ZIP “Zooming In between 195 Plates"). 
REFERENCES

198 Bangs, N.L.B., Gulick, S.P.S., and Shipley, T.H., 2006, Seamount subduction erosion in the Nankai 199 Trough and its potential impact on the seismogenic zone: Geology, v. 34, p. 701-704.

200 Borrero, J.C., Dolan, J.F., and Synolakis, C.E., 2001, Tsunamis within the eastern Santa Barbara 201 Channel: Geophysical Research Letters, v. 28, p. 643-646.

202 203 204

Cloos, M., 1992, Thrust-Type Subduction-Zone Earthquakes and Seamount Asperities - a Physical Model for Seismic Rupture: Geology, v. 20, p. 601-604.

Collot, J.Y., and Fisher, M.A., 1989, Formation of Fore-Arc Basins by Collision between Seamounts and Accretionary Wedges - an Example from the New Hebrides Subduction Zone: Geology, v. 17, p. $930-933$.

Collot, J.Y., Lewis, K., Lamarche, G., and Lallemand, S., 2001, The giant Ruatoria debris avalanche on the northern Hikurangi margin, New Zealand: Result of oblique seamount subduction: Journal of Geophysical Research-Solid Earth, v. 106, p. 19271-19297.

Das, S., and Watts, A.B., 2009, Effect of subducting seafloor topography on the rupture characteristics of great subduction zone earthquakes, in Lallemand, S., and Funiciello, F., eds., Subduction zone geodynamics: Berlin-Heidelberg, Springer, p. 103-18.

Davis, D., Suppe, J., and Dahlen, F.A., 1983, Mechanics of Fold-and-Thrust Belts and Accretionary Wedges: Journal of Geophysical Research, v. 88, p. 1153-1172.

217 Dominguez, S., Malavieille, J., and Lallemand, S.E., 2000, Deformation of accretionary wedges in 218 response to seamount subduction: Insights from sandbox experiments: Tectonics, v. 19, p. 182219 196. 
220 Fisher, M.A., Normark, W.R., Greene, H.G., Lee, H.J., and Sliter, R.W., 2005, Geology and tsunamigenic potential of submarine landslides in Santa Barbara Channel, Southern California: Marine Geology, v. 224, p. 1-22.

223 224 225

Geersen, J., Ranero, C.R., Barckhausen, U., and Reichert, C., 2015, Subducting seamounts control interplate coupling and seismic rupture in the 2014 Iquique earthquake area: Nature Communications, v. 6 .

Gerya, T., 2010, Introduction to Numerical Geodynamic Modelling, Cambridge University Press, 345 p.

Gerya, T., and Yuen, D.A., 2007, Robust characteristics method for modelling multiphase visco-elastoplastic thermo-mechanical problems: Physics of the Earth and Planetary Interiors, v. 163, p. 83105.

Hampton, M.A., Lee, H.J., and Locat, J., 1996, Submarine landslides: Reviews of Geophysics, v. 34, p. 33-59.

Hillier, J.K., and Watts, A.B., 2007, Global distribution of seamounts from ship-track bathymetry data: Geophysical Research Letters, v. 34.

Huhnerbach, V., Masson, D.G., Bohrmann, G., Bull, J.M., and Weinrebe, W., 2005, Deformation and submarine landsliding caused by seamount subduction beneath the Costa Rica continental margin-new insights from high- resolution sidescan sonar data: Submarine Slope Systems: Processes and Products, v. 244, p. 195-205.

Lallemand, S.E., and Le Pichon, X., 1987. Coulomb wedge model applied to the subduction of seamounts in the Japan Trench. Geology, v. 15, p. 1065-1069.

Lallemand, S.E., Culotta, R., von Huene, R., 1989. Subduction of the Daiichi-Kashima seamount in the Japan Trench. Tectonophysics, v. 160, p. 231-247.

Lallemand, S.E., Malavieille, J., Calassou, S., 1992. Effects of oceanic ridge subduction on accretionary wedges: Experimental modeling and marine observation. Tectonics, v. 11, p. 1301- 
246 Laursen, J., Scholl, D.W., and von Huene, R., 2002, Neotectonic deformation of the central Chile margin: Deepwater forearc basin formation in response to hot spot ridge and seamount subduction: Tectonics, v. 21.

Lewis, K.B., Collot, J.Y., and Lallemand, S.E., 1998, The dammed Hikurangi Trough: a channel-fed trench blocked by subducting seamounts and their wake avalanches (New Zealand-France GeodyNZ Project): Basin Research, v. 10, p. 441-468.

Lewis, K.B., Lallemand, S., and Carter, L., 2004, Collapse in a Quarternary shelf basin off East Cape, New Zealand: evidence for passage of a subducted seamount inboard of the Ruatoria giant avalanche: New Zealand Journal of Geology and Geophysics, v. 47, p. 415-429.

Liu, J., Tian, J.L., and Yi, P., 2015, Impact forces of submarine landslides on offshore pipelines: Ocean Engineering, v. 95, p. 116-127.

Mochizuki, K., Yamada, T., Shinohara, M., Yamanaka, Y., and Kanazawa, T., 2008, Weak interplate coupling by seamounts and repeating M similar to 7 earthquakes: Science, v. 321, p. 1194-1197.

Nishizawa, A., Kaneda, K., Watanabe, N., and Oikawa, M., 2009, Seismic structure of the subducting seamounts on the trench axis: Erimo Seamount and Daiichi-Kashima Seamount, northern and southern ends of the Japan Trench: Earth Planets and Space, v. 61, p. E5-E8.

Oakley, A.J., Taylor, B., and Moore, G.F., 2008, Pacific Plate subduction beneath the central Mariana and Izu-Bonin fore arcs: New insights from an old margin: Geochemistry Geophysics Geosystems, v. 9.

Park, J.O., Tsuru, T., Kaneda, Y., Kono, Y., Kodaira, S., Takahashi, N., and Kinoshita, H., 1999, A subducting seamount beneath the Nankai accretionary prism off Shikoku, southwestern Japan: Geophysical Research Letters, v. 26, p. 931-934. 
Pedley, K.L., Barnes, P.M., Pettinga, J.R., and Lewis, K.B., 2010, Seafloor structural geomorphic evolution of the accretionary frontal wedge in response to seamount subduction, Poverty Indentation, New Zealand: Marine Geology, v. 270, p. 119-138.

Ruh, J.B., Gerya, T., and Burg, J.P., 2013, High-resolution 3D numerical modelling of thrust wedges: Influence of decollement strength on transfer zones: Geochemistry Geophysics Geosystems, v. 14, p. $1131-1155$.

Ruh, J.B., Gerya, T., and Burg, J.P., 2014, 3D effects of strain vs. velocity weakening on deformation patterns in accretionary wedges: Tectonophysics, v. 615, p. 122-141.

Schmidt, R., and Schmincke, H.U., 2002, From seamount to oceanic island, Porto Santo, central EastAtlantic: International Journal of Earth Sciences, v. 91, p. 594-614.

Scholz, C.H., and Small, C., 1997, The effect of seamount subduction on seismic coupling: Geology, v. 25, p. 487-490.

Smith, D.K., and Jordan, T.H., 1988, Seamount Statistics in the Pacific-Ocean: Journal of Geophysical Research-Solid Earth and Planets, v. 93, p. 2899-2918.

Tappin, D.R., Grilli, S.T., Harris, J.C., Geller, R.J., Masterlark, T., Kirby, J.T., Shi, F.Y., Ma, G.F., Thingbaijam, K.K.S., and Mai, P.M., 2014, Did a submarine landslide contribute to the 2011 Tohoku tsunami?: Marine Geology, v. 357, p. 344-361.

Timm, C., Bassett, D., Graham, I.J., Leybourne, M.I., de Ronde, C.E.J., Woodhead, J., LaytonMatthews, D., and Watts, A.B., 2013, Louisville seamount subduction and its implication on mantle flow beneath the central Tonga-Kermadec arc: Nature Communications, v. 4.

von Huene, R., 2008, Geophysics - When seamounts subduct: Science, v. 321, p. 1165-1166. von Huene, R., Ranero, C.R., and Watts, P., 2004, Tsunamigenic slope failure along the Middle America Trench in two tectonic settings: Marine Geology, v. 203, p. 303-317.

von Huene, R., Bourgouis, J., Miller, J., and Patout, G., 1989, A large tsunamigenic landslide and debris flow along the Peru trench: Journal of Geophysical Research, v. 94, p. 1703-1714. 
von Huene, R., Reston, T., Kukowski, N., Dehghani, G.A., Weinrebe, W., LePichon, X., Pascal, G., Lallemant, S., LeMeur, D., ChamotRooke, N., Loucoyannakis, M., Babassilas, D., Nicolich, R., Cernobori, L., Westbrook, G., Warner, M., Tay, P.L., Jones, K., Lonergan, L., Dickmann, T., and Fruehn, J., 1997, A subducting seamount beneath the Mediterranean Ridge: Tectonophysics, v. 271, p. 249-261.

Wang, K., and Bilek, S.L., 2011, Do subducting seamounts generate or stop large earthquakes?: Geology, v. 39, p. 819-822.

Watts, A.B., Koppers, A.A.P., and Robinson, D.P., 2010, Seamount Subduction and Earthquakes: Oceanography, v. 23, p. 166-173.

Wells, R.E., Weaver, C.S., and Blakely, R.J., 1998, Fore-arc migration in Cascadia and its neotectonic significance: Geology, v. 26, p. 759-762.

Wessel, P., Sandwell, D.T., and Kim, S.S., 2010, The Global Seamount Census: Oceanography, v. 23, p. 24-33.

\section{FIGURE CAPTIONS}

Figure 1 Surface topography of 3D accretionary wedges above initial sediment thickness in map view after 9 Myr experiment time. Backstop is located at $x=0$ on the upper side of the plates. (a) No seamount implementation. (b-e) Conical seamount implementation. Dots indicate location of seamount peaks. (f-i) Flat-topped seamount implementation. Circles indicate location of flat area of seamount tops. Height of seamounts is indicated on top for all columns.

Figure 2 Surface topography peaks related to seamount subduction (Fig. 1) are plotted against the complete volume of according implemented seamounts for an experiment time of 7, 8 and 9 Myr. Circles and squares indicate conical and flat-topped seamounts, respectively. Seamount heights are 1.5, 3, 4.5, $6 \mathrm{~km}$ above décollement level, increasing towards right according to their volume. 
319 Figure 3 (a) Compositional map, (b) strain rate, and (c) velocity in $x$-direction of an accretionary

320 wedge indented by a $6 \mathrm{~km}$ high flat-topped seamount after 9 Myr shortening. Wedges are cut parallel to $321 x$-direction at $y=44.8 \mathrm{~km}$. Seamounts are displayed by their composition.

323 Figure 4 Dynamics of numerical landslides. (a,b) Temporal surface taper evolution of reference and 324 landslide-generating experiments. Dotted line: no seamount implementation. Grey line: $4.5 \mathrm{~km}$ high 325 seamount. Black line: $6 \mathrm{~km}$ high seamount. Dashed lines: Minimum and maximum critical taper angles 326 (Davis et al., 1983). (c,d) Volume of landslides triggered by conical and flat-topped seamounts, 327 respectively. Filled areas indicate volumes between $0.5 \mathrm{~cm} / \mathrm{yr}<v_{x}<1 \mathrm{~cm} / \mathrm{yr}$ moving against shortening 328 direction. Dashed lines indicate volume of seamounts overtopping the initial sedimentary stratigraphic 329 thickness. Grey: $4.5 \mathrm{~km}$ high seamount. Black: $6 \mathrm{~km}$ high seamount.

331 Figure 5 Comparison between natural and numerical cases. (a) Top view of an experiment with a $6 \mathrm{~km}$ 332 high flat-topped seamount after 9 Myr. Grey scale background: surface topography. Red lines:

333 numerical faults. Blue tones: different landslides. Rose: landslide detachment. Blue and rose stripes: 334 detachment burried by landslide. (b) Profiles in $x$-direction at $L y=0.5$ of the experiment presented in 335 (a) before and after landslide occurrence at 7.4 and 9 Myr. Lower panel: surface lines before (red) and 336 after (green) landsliding corrected for seamount passage (measured surface lines minus height of 337 seamounts exceeding the initial sedimentary strata). Colors as in (a). (c) Simplified map of the Ruaroria 338 indentation at the northeastern tip of Newzealand (after Collot et al., 2001; Lewis et al., 2004).Dark 339 grey: upper margin. Light grey: imbricated zone. Dotted area: debris flow and disturbed trench fill.

340 Lined area: post-avalanche turbidites. Red lines: main faults. Broken red line: pre-avalanche 341 deformation front. Arrow: direction of plate motion and location of seamount entrance. Blue and rose 342 as in (a). (d) Profiles through the Ruatoria indentation (after Collot et al., 2001). Profile A-A' indicates 
343 imbricate margin lacking a recent accretionary wedge. Dark grey: Neogene and Quaternary deposits.

344 Light grey: imbricate zone. Profile B-B' shows cross section before (red) and after (green) avalanching.

345 Black line: base of landslide. Color code equal to (a). 